\title{
Penyuluhan Tentang Kewirausahaan Melalui Media Sosial Kepada Ibu-Ibu PKK Di Wilayah Kelurahan Abadijaya, Sukamaja, Depok
}

\author{
Pramudianto ${ }^{1}$, Ika Pratiwi ${ }^{2}$ \\ ${ }^{1}$ Dosen Program Studi Magister Manajemen Universitas Bina Bangs \\ ${ }^{2}$ Mahasiswa Program Studi Magister Manajemen Universitas Bina Bangsv \\ e-mail:ppramudianto28@gmail.com
}

\begin{abstract}
Family Welfare Development(In short is PKK), is a community organization that empowers women to participate in Indonesia's development. The PKK main programs are basically basic human needs, one of which is education and skills. This PKM activity aims to provide counseling for basic needs which are the main programs of PKK mothers. This counseling contains how to do entrepreneurship in social media .. Facebook and Instagram are being socialized. Online business opportunities, provide benefits for PKK mothers, with relatively small capital, do not take up time, and can be done at home. The results of this activity can provide them with the opportunity to sell (business) with the provision of ethical use of social media in order to attract, as well as customer trust. PKK mothers as partners in the community service activities, are very interested in learning the material provided about entrepreneurship through social media.
\end{abstract}

Keywords: PKK, social media, intreprenuership, online bussiness

\begin{abstract}
Abstrak
Pembinaan Kesejahteraan Keluarga, disingkat PKK, adalah organisasi kemasyarakatan yang memberdayakan wanita untuk turut berpartisipasi dalam pembangunan Indonesia. 10 Program Pokok PKK pada hakekatnya merupakan kebutuhan dasar manusia, salah satu diantaranya yaitu pendidikan dan keterampilan. Kegiatan PKM ini bertujuan memberikan penyuluhan untuk kebutuhan dasar yang menjadi program pokok ibu - ibu PKK. Penyuluhan ini berisikan bagaimana berwirausaha di media sosial.. Facebook dan Instagram yang disosialisasikan. Peluang usaha online, memberikan keuntungan bagi ibu - ibu PKK, dengan modal relatif kecil, tidak menyita waktu, dan bisa dilakukan dirumah. Hasil kegiatan abdimas ini dapat memberikan mereka kesempatan untuk berjualan (bisn is) dengan bekal etika penggunaan media sosial agar dapat untuk menarik, serta kepercayaan pelanggan. Ibu - ibu PKK selaku mitra dalam kegiatan abdimas, sangat tertarik untuk mempelajari materi yang diberikan mengenai wirausaha melalui media sosial.
\end{abstract}

Kata kunci: PKK, Media Sosial, intrerpreneur, bisnis online

\section{PENDAHULUAN}

Membangun suatu usaha baik itu usaha kecil, menengah, ataupun usaha besar diperlukan suatu peranan teknologi infomasi di dalamnya. Dengan informasi yang kita miliki dapat membantu untuk mengambil keputusan yang tepat, dan ditambah dengan adanya teknologi yang terkoneksi jaringan internet global yang memberikan kemudahan dalam pemasaran produk atau jasa. Menurut Dr. Alfred Osborne, Jr, Direktur Pusat Studi KeWirausahaan, di Universitas California, menegaskan bahwa informasi dan kebutuhan untuk menggunakan sumber-sumber informasi dapat menciptakan peluang bisnis yang amat

\footnotetext{
${ }^{1}$ Dosen tetap Prodi Magister Manajemen Univeritas Bina Bangsa

${ }^{2}$ Mahasiswa Prodi Magister Manajemen Univeritas Bina Bangsa
} 
banyak. Mengapa demikian, karena kunci sukses kebehasilan berwirausaha terletak dalam memperoleh dan mengelola informasi.

Peranan teknologi dalam bidang usaha pemasaran yaitu menunjang kegiatankegiatan yang saling berhubungan dan ditujukan untuk merencanakan, menentukan harga, mempromosikan, serta mendistribusikan barang dan jasa kepada pembeli. Selain di bidang pemasaran, teknologi juga berperan dalam rangka pengelolaan jaringan, sistem tagihan, persediaan, dan berbagai aplikasi lain yang terkait dengan kegiatan operasi serta sistem keuangan, personalia dan beragam aplikasi lain yang terkait dengan manajemen.(SDM) TIK, mulai dari keterampilan dan pengetahuan, perencanaan, pengoperasian, perawatan dan pengawasan, serta peningkatan kemampuan TIK para pimpinan di lembaga pemerintahan, pendidikan, perusahaan, UKM (usaha kecil menengah) dan LSM. Sehingga pada akhirnya akan dihasilkan output yang sangat bermanfaat baik bagi manusia sebagai individu itu sendiri maupun bagi semua sektor kehidupan (Pikiran Rakyat, 2005:Maret).

Wirausaha adalah suatu proses peningkatan kesejahteraan yang dinamis, kesejahteraan diciptakan oleh yang menghadapi resiko terbesar dari sisi equity (modal), waktu, dan komitmen untuk memberi nilai untuk suatu produk atau jasa. Menurut Winarso Drajat Widodo (2005), wirausaha adalah usaha atau bisnis yang selalu berusaha memindahkan segala sumber daya ekonomi dari wilayah yang kurang produktif ke wilayah yang lebih produktif agar memperoleh penghasilan yang lebih besar, dan semakin besar. Pendapat lain dari Rambat Lupiyoadi Jero Wacik (1998) mendifinisikan bahwa wirausaha adalah kegiatan yang melaksanakan proses penciptaan kekayaan dan nilai tambah melalui peneloran dan penetasan gagasan, memadukan sumber daya dan merealisasikan gagasan tersebut menjadi kenyataan. Seseorang yang berwirausaha adalah orang yang menjalankan usaha atau perusahaan dengan kemungkinan untung atau rugi.Oleh karena itu wirausaha perlu memiliki kesiapan mental, baik untuk menghadapi keadaan merugi maupun untung besar. Beragam cara dilakukan oleh para pewirausaha (entrepreneur) untuk menjalankan roda usahanya. Salah satu cara yang cukup banyak dilakukan oleh para entrepreneur adalah menggunakan teknologi sebagai alat untuk menjalankan bisnisnya.

Kurangnya pengetahuan dan pemahaman ibu-ibu PKK di wilayah RT.06 RW.02 dan RT.08 RW.02, Kelurahan Abadijaya Kecamatan Sukmajaya Kota Depok tentang media sosial. Oleh karena itu, tim abdimas merasa perlu memberikan bekal pengetahuan dengan memberikan dasar - dasar informasi mengenai media sosial khususnya facebook dan instagram kepada ibu-ibu PKK RT.06 RW.02 dan RT.08 RW.02.

Adapun tujuan kegiatan dari abdimas ini adalah untuk menjalankan dan mewujudkan salah satu tugas serta tanggung jawab dari Tridarma Perguruan Tinggi dalam mengabdikan ilmu yang dimiliki bagi masyarakat dengan memberikan pengetahuan melalui penyuluhan dan pelatihan kepada ibu-ibu PKK RT.06 RW.02 dan RT.08 RW .02 tentang media sosial. 


\section{METODE}

Pelaksanaan penyuluhan dilakukan di rumah ketua rukun tetangga RT.06 RW.02 JI. Maliki I, Kelurahan: Abdijaya, Kecamatan: Sukmajaya, Depok II Timur. Penyuluhan ini di peruntukan bagi ibu-ibu PKK RT.06 RW.02 dan RT.08 RW.02, dengan tahapan sebagai berikut :

1. Melakukan kunjungan dengan ketua rukun tetangga setempat masing - masing, untuk menyampaikan maksud Tim Abdimas ke lokasi. Dan sasaran yang diberikan adalah ibu-ibu PKK RT.06 RW.02 dan RT.08 RW.02.

2. Tim abdimas menganalisa kebutuhan mitra, mengumpulkan bahan dan materi yang akan digunakan untuk penyuluhan kepada kedua rukun tetangga tersebut.

3. Pelaksanaan abdimas.

4. Pelatihan diberikan kepadaibu-ibu PKK RT.06 RW.02 dan RT.08 RW.02 dilokasi yang sudah disiapkan oleh pihak Mitra Abdimas, yaitu di rumah ketua rukun tetangga RT.06 RW.02.

5. Pelaporan Kegiatan

6. Melakukan sejumlah analisa terhadap hasil kegiatan dan mengambil kesimpulan untuk dapat dilakukan perbaikan pada kegiatan abdimas selanjutnya..

\section{HASIL DAN PEMBAHASAN}

\section{Kegiatan Pendahuluan}

1. Perizinan

Pada tanggal 2 Maret 2020 tim abdimas mengirim surat permohonan kepada mitra tentang pengadaan Penyuluhan Tentang Kewirausahaan Melalui Media Sosial Kepada Ibu-ibu PKK Di Wilayah RT.06/RW.02 Dan RT.08/RW.02, Kelurahan Abadijaya, Kecamatan Sukmajaya, Kota Depok.

2. Pendataan Ibu-ibu PKK RT.06/RW.02 Dan RT.08/RW.02

Setelah mendapat izin dari pihak mitra, kemudian tim abdimas melakukaan pendataan Ibu-ibu PKK untuk menindak lanjuti penyuluhan tentang kewirausahaan melalui media sosial.

\section{Observasi Lapangan (25-28 Maret 2020)}

1. Pertemuan dengan Ketua RT .06/RW.02 Dan RT.08/RW.02

Kegiatan ini kami lakukan untuk menggali data dan informasi tentang ibu-ibu dalam kemampuan mengetahui tentang kewirausahaan melalui media sosial.

2. Analisi Permasalahan Mitra

Dari hasil temuan data dan informasi, dihasilkan kendala atau masalah dalam hal keterampilan dan penguasaan tentang kewirausahaan melalui media sosial kepada ibu- ibu PKK, sebagai berikut: 
Kurangnya pengetahuan dan pemahaman ibu-ibu PKK baik di Wilayah RT.06/RW.02 dan RT.08/RW.02 tentang kewirausahaan, khususnya kewirausahaan melalui media sosial.

3. Penyusunan Materi Penyuluhan (April 2020)
a. Memberikan pengetahuan awal tentang media sosial.
b. Memberikan contoh penggunaan media sosial untuk kewirausahaan. c. Memberikan contoh kewirausahaan yang di publikasi di media sosial.
c. Memberikan modul dan menjelaskan proses dan langkah-langkah penggunaan media sosial.
d. Melakukan penyuluhan proses penggunaan media sosial.

4. Realisasi Kegiatan Abdimas (3 Mei 2020)

\section{a. Pemberian Materi}

Tim pengabdian masyarakat memberikan materi tentang kewirausahaan melalui media sosial sebagai media pemasaran kewirausahaan berbasis online sdengan tujuan memberikan pengetahuan bahwa media sosial dapat digunakan ibu-ibu PKK dalam pemasaran produk/ barang dagangan nya .

Tim memberikan modul bagaimana pengertian media sosial khususnya facebook dan instagram, cara penguasaan dan penggunaan media sosial.

b. Penyuluhan Kewirausahaan Melalui Media Sosial Kepada Ibu-ibu PKK

Dengan dipandu modul yang telah kami berikan, maka kami memulai penyuluhan. dengan metode penyuluhan satu pemateri menyampaikan di depan, sedangkan peserta penyuluhan mengikuti materi pada modul masing-masing.

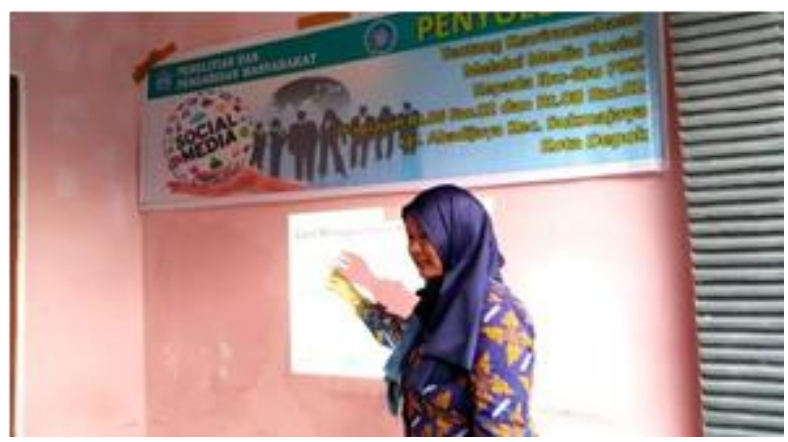

Gambar 1. pemateri saat memberikan penjelasan tentang Media Sosial 


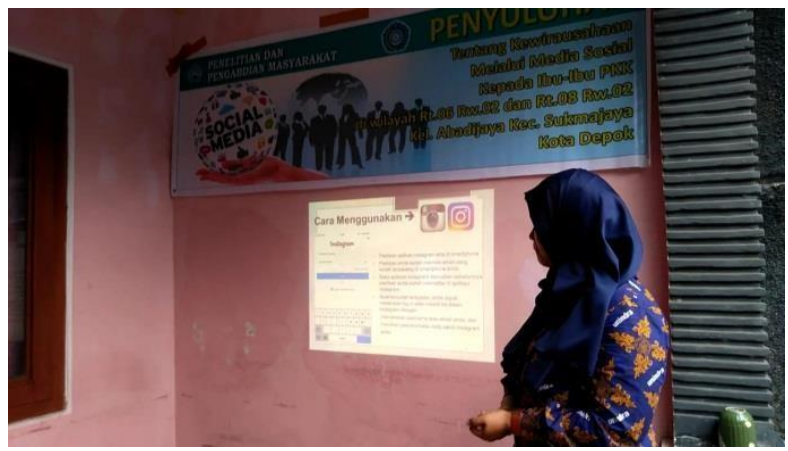

Gambar 2. pemateri saat memberikan penjelasan tentang FB dan Instagram

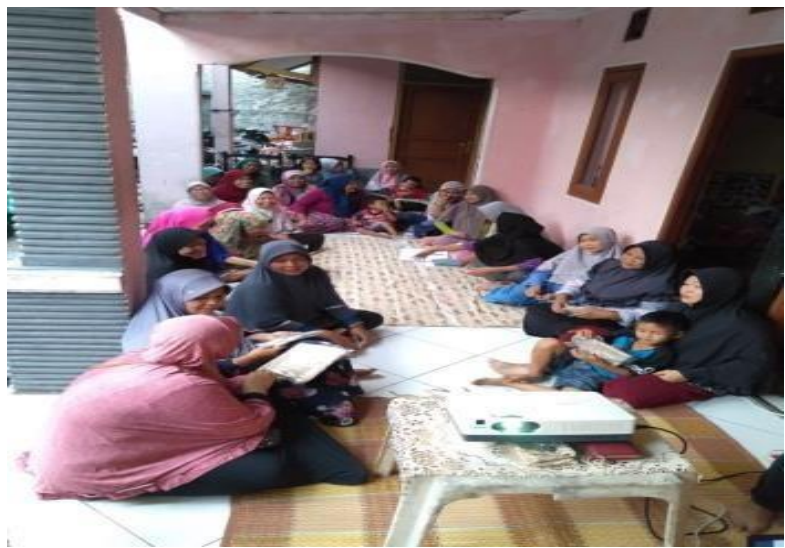

Gambar 3. Ibu ibu PKK mengikuti penyuluhan dengan antausias

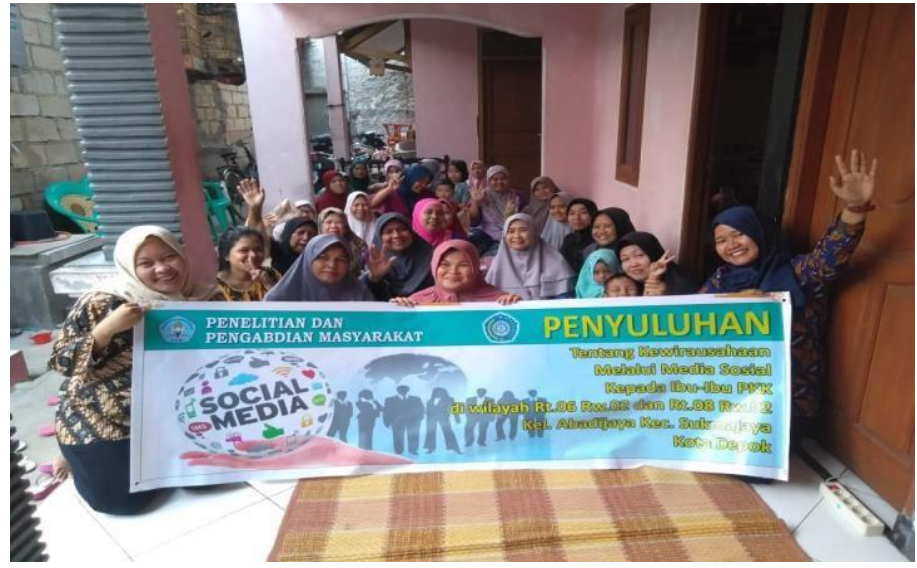

Gambar 4. Pemateri dan ibu-ibu PKK berfoto bersama 


\section{KESIMPULAN}

Walaupun dirasa masih belum sepenuhnya mencapai target dan luaran yang diharapkan, namun kegiatan pengabdian masyarakat ini telah memberikan kontribusi yang positif bagi upaya peningkatan pengetahuan dan kemampuan dalam mengenal dan mengetahui kewirausahaan melalui media sosial kepada ibu-ibu PKK. Kegiatan ini telah berjalan dengan baik dan dapat disimpulkan sebagai berikut:

1. Ibu-ibu PKK RT.06/RW.02 dan RT.08/RW.02 antusias dalam pelaksanaan kegiatan dan mulai timbul ketertarikan dalam mempelajari kewirausahaan melalui media sosial.

2. ibu-ibu PKK RT.06/RW.02 dan RT.08/RW.02 mampu membuat dan menjalankan program pemasaran kewirausahaan melalui media sosial dari penyuluhan yang diberikan menggunakan media sosial yang berkaitan dengan kewirausahaan.

\section{UCAPAN TERIMA KASIH}

Dengan telah dilaksanakan kegiatan Pengabdian Kepada masyarakat (PKM), penulis mengucapkan terima kepada :

1. Ibu-ibu PKK di wilayah RT.06 RW.02 dan RT.08 RW.02, Kelurahan Abadijaya Kecamatan Sukmajaya Kota Depok;

2. Rektor Universitas Bina Bngsa, yang telah mendukung dan memfasilitasi kegiatan PKM ini.

\section{DAFTAR PUSTAKA}

Lesmana, G. N. A. (2012). Analisis Pengaruh Media Sosial Twitter Terhadap Pembentukan Brand Attachment (Studi: PT. XL AXIATA), Tesis. Program Magister Manajemen, Fakultas Ekonomi, Universitas Indonesia

Nordiana, E. (2013). Peran jejaring sosial sebagai media peningkat minat berwirausaha mahasiswa untuk berbisnis online (studi pada mahasiswa jurusan ilmu ekonomi Universitas Brawijaya). Jurnal IImiah Mahasiswa FEB, 2(2).

Thobias, E. (2013). Pengaruh modal sosial terhadap perilaku kewirausahaan (suatu studi pada pelaku usaha mikro kecil menengah di Kecamatan Kabaruan Kabupaten Kepulauan Talaud). ACTA DIURNA KOMUNIKASI, 2(2).

https://seon.co.id/pengertian-media-sosial-facebook-twitter-google-youtubeinstagram (diakses pada tanggal 10 Mei 2020) 